\title{
ANALISIS YURIDIS PERAN BIDAN PUSKESMAS TERHADAP UPAYA PROMOTIF DETEKSI DINI KANKER SERVIKS
}

\author{
Nurul Soimah \\ Program Studi Kebidanan Diploma III Universitas Aisyiyah Yogyakarta, Program Studi Kebidanan Program Sarjana Terapan \\ Kebidanan Universitas 'Aisyiyah Yogyakarta Jalan Siliwangi No.63 Ring Road Barat Nogotirto Gamping Sleman \\ Yogyakarta085725200451. \\ Email: nurul shoimah@unisayogya.ac.id.
}

\begin{abstract}
ABSTRAK
Promosi kesehatan merupakan langkah awal pada upaya mewujudkan peningkatan derajat kesehatan masyarakat, Peran Bidan di Wilayah Kerja Puskesmas Tempel pada upaya promosi deteksi dini kanker didapatkan masih kurang. Penelitian dilakukan untuk menggali tentang kebijakan program dan peran bidan pada upaya promosi deteksi dini kanker rahim, dengan metode studi kasus, tehnik sampling yang digunakan adalah purpossive sampling dengan pendekatan Indepth Interviews (IDIs atau wawancara mendalam) dilakukan pada 5 Informan, yaitu pada 1 bidan koordinator puskesmas, 2 bidan koordinator program Promosi kesehatan dan Posyandu, dan 1 bidan pelaksana program, dan 1 triangulasi sumber yaitu pejabat struktural Puskesmas.Didapatkan bahwa pelaksaan kebijakan program belum merata, hal tersebut disebabkan karena keterbatasan sumberdaya tenaga bidan yang masih merangkap jabatan pada setiap jobdiskripsi tugas, sehingga cakupan yang menjadi target sasaran hanya bisa dilaksanakan pada batas program minimal yaitu promosi tahunan yang diprogramkan 2 kali pertahun.Selama peiode 2019 tidak didapatkan hasil Pemeriksaan IVA maupun papsmear yang mengarah pada tanda keganasan.
\end{abstract}

Kata Kunci : deteksi kanker; peran bidan; promosi kesehatan

\begin{abstract}
Health promotion is the first step in an effort to realize an increase in community health status. The role of midwives in Tempel district health center in promoting early detection of cancer is still lacking (Fitri, S, 2016). this research was conducted to explore program policies and the role of midwives in promotion efforts. early detection of uterine cancer, with the case study method, the sampling technique used was pusposive sampling with the Indepth Interview approach (IDIs or in-depth interviews), conducted on 5 informants, namely at 1 coordinator midwife of district health center, 2 midwives coordinator of the health promotion program and Integrated Health Post, and 1 practice midwife, and 1 triangulation of source, namely district health center official. It was found that the implementation of program policies was not evenly distributed, this was due to the limited resources of midwives who were concurrently holding positions at each job description, so that the scope of the targeted targets could only be carried out at the program boundary minimaly, which is an annual promotion programmed twice a year. During the 2019 period, there were no results of the IVA examination or pap smear that led to the sign of malignancy.
\end{abstract}

Keywords: cancer detection; health promotion; role of midwives. 


\section{PENDAHULUAN}

Bidan memiliki peran penting pada pembangunan bidang kesehatan sebagaimana tertuang didalam konsep kebidanan bahwa bidan sebagai provider memiliki tanggng jawab dalam hal promosi dan preventif, Tuntutan terhadap tugas bidan adalah selalu berhadapan dengan sasaran dan target pelayanan kebidanan dan pelayanan kesehatan masyarakat dengan memperkuat kepercayaan, sikap, ilmu pengetahuan, dan sejumlah keahlian yang telah diterima dan berguna bagi masyarakat. Rencana Strategis Dinas Kesehatan Sleman Tahun 2016-2021 disusun berdasarkan laporan target cakupan tahun sebelumnya, Target cakupan pelayanan upaya promosi kesehatan reproduksi deteksi dini kanker servik masuk kedalam target sasaran cakupan secara khusus, dan masuk kedalam tantangan dan peluang pada sektor cakupan penyakit tidak menular, (Renstra Dinas Kesehatan Sleman tahun 2016-2020) Salah Satu Misi Dinas kesehatan Sleman adalah "Meningkatkan pelayanan pendidikan dan kesehatan yang berkaulitas dan menjangkau semua lapisan masyarakat", salah satunya adalah Program promosi kesehatan dan pemberdayaan masyarakat,keberhasilan pembangnunan kesehatan Indonesia didukung dengan adanya peran serta masyarakat, peran serta masyarakat dapat diimplementasikan melalui kegiatan posyandu melalui pengelolaan oleh kader dan bidan yang berwenang pada pemantauan wilayah setempat pada daerah bianaannya adanya kerjasama lintas sektoral, Permasalahan pelayanan Sistem Kesehatan pelayanan dasar adalah kurangnya PNS untuk pelayanan kesehatan masyarakat dan penyakit tidak menular yang makin mengancam kesehatan masyarakat (Depkes RI, 2011).

Peran Promosi kesehatan sangat diperlukan pada upaya pencegahan suatu penyakit, Jurnal penelitian di Yogyakarta yang dilakukan dengan metode pre dan post test didapatkan bahwa antara pengetahuan sebelum penyuluhan dan sesudah terdapat perbedaan pada pengaruh pada pengambilan keputusan dari 36 responden dengan kriteria baik sebelum adalah $55 \%$, sesudah penyuluhan menjadi $94,5 \%$.
Mengacu pada hasil penelitian Nurul S (2017) di dusun Ganggom, Turi,Sleman, dengan judul pengetahuan pasangan usia subur (PUS) tentang kanker rahim didapatkan hasil bahwa dari hasil FGD 9 informan didapatkan belum mengetahui secara benar tentang kanker servis, baik tentang tanda gejala maupun cara pencegahannya.

Pengetahuan merupakan salah satu cara mendasar agar orang mau dan sadar terhadap sesuatu, mengingat bahwa penyakit kanker rahim masih menjadi isu serius di masyarakat, hasil penelitian tersebut menjadi penting untuk mendapatkan perhatian, hal ini dikarenakan masih didapatkannya angka kejadian kanker rahim yang makin meningkat.

Tanggung jawab tenaga kesehatan adalah bagaimana menekan dan menurunkan faktor resiko pada tahap promotif, preventif dan kuratif, faktor promotif berkontribusi berarti melalui peningkatan pengetahuan masyarakat secara berkelanjutan tanpa diskriminasi yang dimulai oleh tenaga kesehatan pada pelayanan tingkat dasar, Sasaran utama dari upaya pencegahan dan penurunan angka kejadian kanker rahim adalah seluruh lapisan masyarakat sebagaimana diamanahkan oleh negara seperti yang yang tercantum dalam Undang-Undang Nomor 36 Tahun 2009, Tentang Kesehatan disebutkan pada muqodimah menimbang "bahwa setiap kegiatan dalam upaya untuk memelihara dan meningkatkan derajat kesehatan masyarakat yang setinggi-tingginya dilaksanakan berdasarkan prinsip non diskriminatif, partisipatif, dan berkelanjutan dalam rangka pembentukan sumber daya manusia Indonesia, serta peningkatan ketahanan dan daya saing bangsa bagi pembangunan nasional;". Perundangan ini sebagai salah satu bentuk ketegasan pemerintah pada upaya pembangunan manusia meuju bangsa yang sehat dan berdaya saing.

Penelitian di Bandung oleh Ermiati (2018) dipaparkan hasil bahwa, Promosi kesehatan tentang deteksi dini kanker rahim dari 37 Nakes yang melakukan 22 orang (60\%), tidak melakukan 15 (40\%), adapun cakupan pelayanan skrining deteksi dini kanker masih rendah (5\%) dibanding standar cakupan 
skrining yang seharusnya 80\%, cakupan skrining ini merupakan salah satu penyebab peningkatan jumlah penderita kanker servik yang terdeteksi sudah pada stadium lanjut (Samadi, 2011).

Peningkatan jumlah angka kejadian kanker rahim seperti yang disebutkan dari Jurnal Penelitian Wulandari, 2008; WHO 2013, disebutkan bahwa pertambahan jumlah penderita kanker serviks yang menyerang pada leher rahim di tandai dengan kurangnya pengetahuan tentang kanker serviks. Tingginya prevalensi penyakit kanker rahim saat ini dipengaruhi oleh beberapa faktor sebagai predisposisi angka kejadian, Menurut RisKesDas (2013) salah satu penyebabnya adalah faktor perokok wanita sebanyak 2,7\%.

Data Dinas Kesehatan (Dinkes) Daerah Istimewa Yogyakarta (DIY, 2014), jumlah kasus Kanker Leher Rahim sebanyak 104 kasus, surveilans terpadu penyakit tidak menular Puskesmas, pada tahun 2014 menunjukkan adanya peningkatan ditiap tahunnya. Selama periode Januari hingga April 2015, angka kesakitan karena kanker serviks yang baru didapatkan 5 orang. Data Dinkes DIY menunjukkan penderita kanker terbanyak berasal dari kalangan usia 25 hingga 64 tahun, ditemukan juga dikalangan usia remaja 15 hingga 24 tahun (Republika, 2015).

Jurnal terkait masalah kanker servik telah dihasilkan oleh beberapa penelitian sebelumnya seperti hasil penelitian yang dilakukan oleh Dewi, Sawitri \& Adiputra (2012) di DIY didapatkan bahwa salah satu faktor resiko kanker servik yang dominan adalah disebabkan oleh Perineal Hygiene yang buruk.

Hasil penelitian Soimah N (2017), pada 7 Pasangan usia Subur, didapatkan bahwa pengetahuan PUS masih kurang dikarenakan belum pernah mendapatkan informasi dan penyuluhan yang jelas tentang penyakit kanker dan bagaimana cara pemeriksaan yang bisa dilakukan dan kemana bisa periksa dengan menggunakan kartu BPJS. Pengetahuan pus tentang penyakit kanker hanya sebatas tahu bahwa kanker adalah penyakit yang mematikan, pengetahuan tentang kanker servik secara spesifik belum terpapar dengan jelas.
Jurnal penelitian fitri Setianingsih (2017), yang dilakukan tahun 2017 di Wilayah kecamatan Tempel didapatkan hasil bahwa pengetahuan WUS yang baik sejumlah 49,5\%, sedangkan upaya pencegahan yang telah dilakukan secara baik didapatkan sejumlah $17,5 \%$.

Hasil penelitian Nurul (2018) didapatkan bahwa peran bidan sebagai provider dalam hal peningkatan pengetahuan masyarakat sebagai upaya promotif dan preventif belum berjalan sebagaimana yang seharusnya bidan berperan. Menurut Kementerian Kesehatan (2010), Bidan Memiliki peran penting pada ketercapaian upaya prefentif perlu dilakukan oleh bidan, data penelitian didapatkan Masalah kesehatan reproduksi wanita cenderung meningkat dari tahun ke tahun. Hal ini perlu adanya keseriusan dalam promosi dan prevensi kesehatan reproduksi wanita di masyarakat. Rumah sakit dan petugas kesehatan merupakan ujung tombak dalam upaya promosi dan prevensi kesehatan. Data Dinkes DIY (2017) dilaporkan tentang ketercapaian PUS usia 30-50 tahun yang melakukan deteksi dini kanker rahim dengan metode IVA didapatkan hasil positif sejumlah $1,14 \%$. Sedangkan pada upaya kesehatan yang telah dilakukan pada upaya penangan komplikasi kebidanan didapatkan cakupan $119.33 \%$, termasuk didalamnya cakupan pelayanan kanker servik.

Kebijakan Pemerintah berperan pada mekanisme pengendalian kanker serviks di Indonesia, tertuang dalam UU No. 36 Tahun 2009 Tentang Kesehatan pasal 161 ayat (3) disebutkan bahwa "manajemen pelayanan kesehatan berupa promotif, preventif, kuratif dan rehabilitatif dititik beratkan pada deteksi dini dan pencegahan penyakit menular seksual".

Peningkatan peran serta masyarakat di DIY dilaksakan dengan meningkatkan peran pembinaan kegiatan posyandu, adapun untuk pencegahan penyakit menular diberdayakan melalui kegiatan Posbindu, total jumlah posbindu di DIY adalah 406 yang tersebar di lima Kabupaten, terbanyak di kaputen Sleman 
sejumlah 206 Posbindu(Profil Keseghatan DIY 2017).

Skrining faktor risiko kanker leher rahim dengan sejumlah 300 sasaran tercapai 225 sasaran, Interpertasi hasil tersebut terdiri dari: Kelas I 200 sasaran,Kelas II 23 sasaran, Kelas III 1 sasaran dan Kelas IV 1 sasaran, Angka kejadian kanker serviks di wilayah Daerah Istimewa Yogyakarta (DIY) sebesar 0,42\% wanita, Riset Kesehatan Dasar (Riskesda, 2013; Dinkes Daerah Istimewa Yogyakarta, 2014). Data ini merupakan bagaian tugas yang harus diselesaikan oleh tenaga kesehatan didukung peran serta masyarakat. Kurang dari $50 \%$ tenaga kesehatan melakukan upaya promosi dan prevensi kesehatan reproduksi pada infeksi pada system reproduksi, deteksi dini, Upaya promosi dan prevensi tentang infeksi saluran reproduksi dan upaya promosi dan prevensi tentang penyakit menular seksual dilakukan sebagian kecil responden, hasil ini menunjukkan bahwa upaya promosi dan prevensi kesehatan reproduksi tentang infeksi pada sistem reproduksi di ruang kebidanan masih rendah. Dari total bidan sejumlah 37 orang yang berperan menjelaskan tentang infeksi saluran reproduksi 21 orang (57\%), tidak menjelaskan 16 (43\%), Menjelaskan tentang penyakit menular seksual 22 Orang (59\%)., tidak menjelaskan 15 (41\%) (Ermiati1, Restuning Widiasih,2018). Tujuan penelitian ini adalah menggali dan menganalisis kebijakan program dan peran bidan pada upaya promosi deteksi dini kanker servik di Wilayah kerja Puskesmas Tempel tahun 2018.

\section{METODE}

Jenis penelitian ini menggunakan metode kualitatif analitik studi kasus, pengambilan data dilakukan secara studi dokumentasi data Dinas Kesehatan Sleman dan wawancara. Penelitian dilakukan untuk menggali tentang kebijakan program dan peran bidan dalam upaya promosi deteksi dini kanker rahim, tehnik sampling yang digunakan adalah purpossive sampling dengan pendekatan Indepth Interviews (IDIs atau wawancara mendalam) dilakukan pada 5 Informan, yaitu pada 1 bidan koordinator Puskesmas, 2 bidan koordinator program Promosi kesehatan dan Posyandu, 1 bidan pelaksana program, dan 1 triangulasi sumber yaitu pejabat struktural Puskesmas. Penelitian dilakukan pada rentang tanggal 5-20 Oktober 2019, Analisa data disusun dan dikategorikan sesuai tema agar didapatkan temuan tema sesuai tujuan penelitian.

\section{HASIL}

Puskesmas Tempel merupakan Puskesmas rawat jalan dan rawat inap 24 jam, PKM Tempel memiliki 11 bidan dengan cakupan Wilayah Kerja terdiri dari 4 Desa dengan jumlah Posbindu sebanyak 60 Posbindu, bidan rawat jalan sejumlah 4 bidan, sedangkan bidan unit rawat inap sejumlah 6 bidan. Pelaksanaan kebijakan program pelayanan kesehatan dilaksanakan oleh semua bidan, baik bidan diunit rawat jalan maupun rawat inap.

Salah satu jobdiskripsi bidan adalah terlibat dalam kegiatan penyuluhan/promosi kesehatan reproduksi dibawah tanggung jawab bidan koordinator program, sedangkan pelaksanaan kegiatan promosi kesehatan merupakan kebijakan lintas program, adapun pelaksanaan promkes dilakukan sesuai prioritas masalah dibawah tanggung jawab koordinator pelaksana kegiatan sesuai bidang keilmuannya.

Peran bidan pada kegiatan promkes deteksi dini kanker dilaksakan sesuai dengan kebijakan program PKM dan sesuai dengan permintaan masyarakat setempat diwilayah kerja PKM Tempel.

\section{Kebijakan dan Peran bidan pada upaya Promosi kesehatan reproduksi deteksi dini Kanker rahim}

"Sesuai kebijakan pemerintah sleman bahwa kebijakan promosi kesehatan reproduksi deteksi dini kanker masuk kedalam program kerja penyakit tidak menular, Kebijakan Promkes deteksi dini kanker dilaksanakan 2 kali dalam 1 tahun diikuti dengan kegiatan pemeriksaan dengan jumlah target sasaran setiap kegiatan adalah 40 PUS.

Namun anggaran tahunan untuk tahun 2020 akan mengalami penurunan 50\% dari anggran tahun 2019, kebijakan ini akan berdampak pad pengurangan anggaran promosi dan pelaksanaan program deteksi dini kanker yang selama ini sudah berjalan 2 kali dalam 1 tahun, untuk kegiatan promosi juga akan berkurang. ( partisipan triangulasi sumber )" 


\section{Kebijakan Puskesmas tentang promosi kesehatan reproduksi perempuan tentang deteksi dini kanker rahim}

"Kebijakan Puskesmas merupakan turunan dari kebijakan Dinas kesehatan, hal tersebut terjadi karena dasar dari setiap kebijakan program adalah disusun berdsarkan hasil capaian dan masalah dimasyarakat dari laporan tahunan sebelumnya, hanya saja disesuaikan dengan skala prioritas masalah yang ada dan dibutuhkan penyelesaian segera. Jobdiskripsi dari pelaksanaan program promkes berada dibawah tanggung jawab unit promkes, namun pada pelaksaannya direalisasikan oleh tenaga kesehatan sesuai bidang keilmuan yang dimiliki.

Untuk pelaksaan promosi kesehatan reproduksi dilaksanakan berdasarkan SPM ( Standar Pelayanan Minimum) berda dibawah tanggung jawab bidan koordinator kespro, SPM dari Program Kespro adalah penyuluhan melalui kegiatan posyandu/ Posbindu yang ada didusun" ( partisipan triangulasi sumber ).

"Pelaksanaan promkes di Posbindu/Posyandu bisa dilaksanakan oleh kader kesehatan yang telah terlatih atau oleh bidan langsung jika masyarakat menghendaki adanya penyuluhan." (Partisipan 2,3).

Penyusunan Program secara langsung bidan koordinator Kespro terlibat langsung karena kebijakan yang disusun berdasarkan pada hasil cakupan tahun sebelumnya yang dilaporakan secara berkala setiap bulan, adapun penyusunan rencana program selanjutnya akan dususun berdasarkan laporan tahunan, mekanisme penyusunan program diajukan ke kepala Puskesmas selanjutnya dilaporkan ke kecamatan, dan Dinkes Kabupaten (partisipan 1, 2)"

\section{Peran Bidan pada promosi Kesehatan reproduksi deteksi dini kanker rahim}

"Peran bidan bertanggung jawab pada wilayah desa wilayah dipegang oleh 4 bidan, khusus kegiatan penyuluhan kespro ada di kegaiatan posyandu, program kegiatan diajukan oleh bidan berkaitan dengan anggaran apakah program disetujui atau tidak, maka baru bisa dilaksanakan jika ada perestujuan anggaran dan rencana, Pelaksaan Promkes deteksi dini kanker dilakukan namun belum bisa menjangkau semua wilayah sesuai jadwal rencana program, kegiatan posbindu dilaksanakan, anggaran kegiatan yang belum terlaksana akan dilakukan pengajuan anggaran untuk tahun selanjutnya. Pelaksaan promkes deteksi dini kanker rahim masih diperlukan dari kesadaran masyarakat, terkadang masyarakat itu harus dioyak oyak dulu untuk mau periksa, sehingga promkes dilakukan lebih mendahulukan dari dasar permintaan masyarakat yang sudah sangat mendesak dan segera" (partisipan 1).

"Kendala pelaksanaan karena tenaga bidan yang ada terbatas 4 bidan penanggung jawab desa yang terbagi menjadi 4 desa saja tidak bisa menjangkau sendiri, sehingga semua bidan yang ada diPuskesmas terlibat pada kegiatan promkes dan posyandu, secara jobdiskripsi bidan sudah terbagi yaitu 6 bidan untuk pelayanan rawat inap dan 4 bidan wilayah, 1 bidan desa, namun pada pelaksanaanya semua masih terlibat sehingga jobdiskripsi tugas memang masih tumpang tindih.namun penanggung jawab program tetap pegang kendali jadwal pelaksaan agar merata ( partisipan 1,3)

"Program posbindu diperbolehkan penyuluhan oleh kader yang sudah terlatih, promkes khusus IVA masih terkendala intinya masyarakat masih malu untuk periksa. Program Kebijakan program promkes kespro khusus IVA dilakuakn $2 x$ setahun' Program diposbindu sebulan sekali dengan membagikan leafleat dan penjelasan olah kader, kader disiapkan dimeja 5 yang bisa dilakuakan oleh nakes.Kebijakan promkes dilakukan secara terpadu sesuai bidang keilmuan nakes yang terlibat.(Partisipan 3)"

"Pelaksanaan promkes dalam bulan ini tidak ada yang terlasana karena waktu untuk menjangkau seluruh posyandu tidak terpenuhi,namun pelayanan kespro dan konseling diPuskesmas tetap jalan dengan jadwal pelaksanaan setiap hari rabu, promkes dan konseling yang dilakuakn juga terbatas pada permasalah gangguan kespro yang dialami jika pasien datang berkunjung untuk periksa, termasuk konseling penyampaian hasilpun harus dilakuakn juka pasien periksa dengan hasil kurang baik, penyampaian hasil dilakukan setelah konseling dan promkes pencegahan dilakukan dan pasien sepakat untuk mengetahui hasil pemeriksaan maka hasil baru bisa dsampaiakn, hal tersebut dilakuakn agar pasien siap dahulu untuk menerima hasil pemeriksaan sehingga psikologi pasien lebih siap.jadi fungsi promkes juga bisa dijalankan secar individu atau keluarga jika pasien datang ke PKM didampngi suami atau keluarga (Partisipan 4,5)"

\section{Hasil cakupan target sasaran promkes deteksi dini kanker rahim}

Informan 2 menyatakan bahwa Sasaran promkes dan pemeriksaan deteksi dini dalam 1 tahun $2 x$, dilakukan untuk, kendala yang didapatkan adalah karena bidan tidak hanya ditugas kebidanan misal bidan juga mendatkan job untuk BOK, Penyuluhan masih hanya sepihak yaitu pihak istri padahal bapak dimasyakat kita adalah pemegang keputusan sehingga kadang juga terbentur pada keputusan suami. Masyarakat masih beranganggapan dan belum merasa penting dan masih memegang budaya rasa malu dengan cara pemeriksaan, Kendala pembiayaan kalau IVA tidak terlalu bermasalah karena hanya dikenakan biaya 25 ribu, dan untuk penggunaan BPJS atau jamkesda memang tidak ada anggaran pemerintah sehingga masyarakat secara mandiri.

Tri Angulasi sumber memaparkan bahwa Promkes deteksi dini kanker secara khusus sudah masuk kedalam program wajib kerja bidan dibawah pengawasan bidan koordinator kesehatan reproduksi, segala rencana program sudah menjadi tanggung jawab bidan koordinator, namun kendala yang ada memang 
menjadi masalah bersama dari Puskesmas, secara pendaan juga ada keterbatasan untuk masalah penanganan deteksi dini kanker servik yang bisa dilaksanakan di Puskesmas adalah pemeriksaan IVA, sehingga pada program pemeriksaan dijadwalkan khusus dalam 1 tahun anggaran hanya 2 kali secara masal, jumlah peserta tidak dibatasi , jika didapatkan tanda gejala keganansan maka langkah selanjutnya adalah rujukan. Kendala tenaga secara jelas memang sudah menjadi permasalahn bersama, apalagi 4 bidan senior yang ada juga sudah memasuki masa persiapan pensiun, sehingga pembagian jobdiskripsi tidak bisa berjalan sesuai, namun diupayakan semua bisa jalan meskipun belum sesuai target sasaran, secara tehnis pelaksanaan promosi kesehatan deteksi dini kanker masuk kedalam program kegiatan posyandu dengan bantuan kader terlatih,

Berkaitan dengan masalah kendala tenaga inlah yang belum bisa diatasi, namun pelaksanaan program dilaksanakan secara fleksibel pada masalah utama yang ada dimasyarakat dan dipilih mana yang menjadi prioritas masalah mendesak, adanya kendala tenaga inilah maka pelaksaaan promosi kesehatan lebih diutamakan sesuai dengan permintaan masyarakat yang dibutuhkan dan diusulkan melalui kader kesehatan yang ada, sehingga diefektifkan pada masalah sesuai dengan kebutuhan masyarakat.

Terkait program kerja yang belum tercapai maka akan diajukan kembali pada anggaran belanja tahun berikutnya.dan dilaporkan ke Dinas kesehatan kabupaten agar masuk sebagai laporan dan dapat disusun ke renstra kabupaten tahun berikutnya....."

\section{PEMBAHASAN}

Kebijakan Dinas Kesehatan kabupaten Sleman tentang peran bidan pada promosi kesehatan reproduksi Deteksi dini kanker Rahim

Undang-Undang Dasar negara Republik Indonesia tahun 1945 menyebutkan bahwa setiap Orang berhak untuk berkomunikasi dan memperoleh Informasi untuk mengembangkan pribadi dan lingkungan sosialnya, serta berhak untuk mencari, memperoleh, memiliki, dan menyimpan Informasi dengan menggunakan segala jenis saluran yang tersedia,

Undang-Undang Nomor 14 tahun 2008 tentang Keterbukaan Informasi Publik Menjelaskan tentang elemen penting penyelenggaraan negara secara terbuka merupakan hak atas informasi publik, Hak setiap orang untuk memeproleh informasi bersifat relevan untuk kepentingan keterlibatan seseorang dalam pengambilan keputusan, partisipasi atau keterlibatan masyarakat. Kedua dasar perundangan tersebut diatas merupakan salah satu dasar pelaksanaan promosi kesehatan.

Salah satu program kegiatan promosi kesehatan di Puskesmas Tempel adalah bidang promosi kesehatan deteksi dini kanker rahim, Promsi kesehatan diperlukan agar masyarakat sasaran tahu arti penting dan tujuan dari promosi dan bisa merubah perilaku seseorang agar mau melakukan deteksi dini,upaya promosi oleh bidan adalah merupakan perwujudan dari penyelenggaraan negara secara terbuka pada pemenuhan hak masyarakat atau perseorangan untuk mendapatkan informasi. Menurut Faizah (2010), Kebijakan Program skrining detksi dini kanker servik sangat penting untuk mencegah kanker serviks, namun program pendidikan dan informatif memainkan peran pentig untuk meningkatkan tingkat keberhasilan skrining. Sesuai dengan rencana startegis dinas kesehatan Sleman tahun 2016-2021 Salah Satu Misi Dinas kesehatan Sleman adalah "Meningkatkan pelayanan pendidikan dan kesehatan yang berkaulitas dan menjangkau semua lapisan masyarakat",.

Berdasarkan hasil yang didapatkan dari Informan 3 dijelaskan bahwa Pelaksaan kebijakan program dilaksanakan pada target sasaran yaitu jumlah Pasangan Usia Subur (PUS) diwilayah kerja Puskesmas, dengan total target sasaran di PKM tempel adalah 4886 PUS. Sesuai dengan cakupan target tahun 2016 yang tercatat didalam perubahan renstra bahwa salah satu kendala pelaksaan program adalah karena kurangnya tenaga pegawai negeri sipil di kabupaten Sleman, Target ini belum terpenuhi, namun pelaksanaan program yang dianggarkan Puskesmas telah tercapai, ketercapaian target sasaran ini bisa terlaksana jika anggaran dana yang seharusnya tersedia, berdasrakan pada kebijakan pemerintah seperti yang tertuang dalam perundang undangan seperti sistem pelayanan BPJS dapat menjangkau pembiayaan dana akan bisa menjadi lebih mudah bagi bidan dan nakes pada pelaksanaan promkes agar dapat menjangkau cakupan masyarakat secara luas,

Pemeriksaan deteksi dini kanker rahim di Puskesmas Tempel di laksanakan dengan 
biaya mandiri oleh peserta, berdasarkan pada jurnal Fitri S,( 2016) disebutkan bahwa salah satu kendala ketercapaian upaya masyarakat melakukan deteksi dini kanker rahim adalah karena masalah kekhawatiran PUS pada masalah biaya yang dikhatirkan tidak terjangaku, kekhawatiran masyarakat tersebut menjadi jelas dengan adanya kebijakan BPJS yang tidak bisa menfasilitasi pembiayaan pemeriksaan melalui penggunaan dana BPJS.Peraturan badan Penyelnggaraan Jaminan Sosial no 1 Tahun 2014 tentang BPJS tercantum pada pasal 25 ayat( 2) yang berisikan tentang manfaat kepsertaan berkaitan dengan hak dan kewajiabn peserta BPJS, hal tersebut jika dianalogkan dengan isi pasal tersbut yang paling dasar tentang promosi kesehatan belum terpenuhi shingga tidak akan tercapai azas manfaat dai pelayanan kesehatan paripurna, analisi lebih luas Jika dinalogkan dengan teori Grendile SM maka analisis dari implementasi kebijakan tersebut terkendala oleh adanya faktor isi kebijakan (conten of policy) dan lingkungan implemntasi (contexc Of Implementatio).

Berdasarkan hasil wawancara didapatkan bahwa, "Penyusunan Program secara langsung bidan koordinator Kespro terlibat langsung karena kebijakan yang disusun berdasarkan pada hasil cakupan tahun sebelumnya yang dilaporakan secara berkala setiap bulan, adapun penyusunan rencana program selanjutnya akan dususun berdasarkan laporan tahunan, mekanisme penyusunan program diajukan ke kepala Puskesmas selanjutnya dilaporkan ke kecamatan, dan Dinkes kabupaten.(partisipan 1, 2)".

Berdasarkan pada hasil dari Triangulasi sumber dipaparkan bahwa Peningkatan akses layanan bagi seluruh masyarakat merupakan salah satu kebijakan khusus Dinkes Sleman, sedangkan Promosi kesehatan adalah masuk kedalam Program Pembangnuan Urusan wajib Kesehatan. Mengacu pada hasil wawancara terkait hambatan program terdapat permasalahan yang perlu pemecahan, perbandingan program dan ketersediaan tenaga adalah merupakan permasalahan dasar yang menjadi kendala ketercapaian, kendala pelaksanaan karena tenaga bidan yang ada terbatas 4 bidan penanggung jawab desa yang terbagi menjadi 4 desa saja tidak bisa menjangkau sendiri, sehingga semua bidan yang ada diPuskesmas terlibat pada kegiatan promkes dan posyandu, secara jobdiskripsi bidan sudah terbagi yaitu 6 bidan untuk pelayanan rawat inap dan 4 bidan wilayah, 1 bidan desa, namun pada pelaksanaanya semua masih terlibat sehingga jobdiskripsi tugas memang masih tumpang tindih.namun penanggung jawab program tetap pegang kendali jadwal pelaksaan agar merata ( partisipan 1,3. Hasil ini didukung dari keterangan triangulasi sumber dijelaskan bahwa "Kendala tenaga secara jelas memang sudah menjadi permasalahn bersama, apalagi 4 bidan senior yang ada juga sudah memasuki masa persiapan pensiun, sehingga pembagian jobdiskripsi tidak bisa berjalan sesuai, namun diupayakan semua bisa jalan meskipun belum sesuai target sasaran, secara tehnis pelaksanaan promosi kesehatan deteksi dini kanker masuk kedalam program kegiatan posyandu dengan bantuan kader terlatih, Penelitian oleh Gilang A.P. 2014, dipaparkan bahwa penurunan fungsi posyandu dapat menurunkan kualitas posyandu yang dapat diakibatkan oleh faktor kurangnya jumlah kader dan bidan.

Berdasarkan hasil penelitian didapatkan bahwa, Hambatan pada ketercapaian deteksi dini kanker rahim selain dari faktor kebijakan dan pelaksanan program, terdapat juga permasalahan dari pihak masyarakat, salah satunya adalah karena faktor pemegang keputusan dalam keluraga adaah suami ( Informan 1 ), selain itu juga karena faktor keterbatsan sumber daya kesehatan dalam hal ini jumlah tenaga bidan diwilayah kerja belum bisa menjangkau masyarakat sasaran, mengacu pada hasil tersebut jika dianalogkan dengan PMK No 97 tahun 2014 Tentang, penyelenggaraan pelayanan kesehatan masa sebelum hamil, bersalin dan masa setalah melahirkan penyelenggaraan pelayana kontrasepsi, Pasal 1 ayat(5) serta pelayanan kesehatan seksual tentang pelayana kesehatan seksual bertujuan Menjamin kesehatan ibu 
sehingga mampu melahirjkan anak berkualitas, menjamin tercapaianya kualitas hidup dan pemenuhan hak-hak reproduksi. Pasal 3 Pemerintah Pusat, Provinsi, Kota, Daerah menjamin ketersediaan sumberdaya kesehatan, sarana dan prasarana dan penyelenggaraan pelayanan kesehatan masa sebelum hamil, bersalin dan nifas, penyelenggaraan pelayana kontrasepsi, serta pelayanan kesehatan seksual, Pasal (4) pelayanan kesehatan masa sebelum hamil, bersalin dan nifas, penyelenggaraan pelayana kontrasepsi, serta pelayanan kesehatan seksual diselenggarakan dengan pendekatan promotif, prefentis, Kuratif, Rehabilitatif yang dilaksanakan secara menyeluruh, terpadu dan berkesinambungan (2) pelayanan kesehatan masa sebelum hamil, bersalin dan nifas, penyelenggaraan pelayana kontrasepsi, serta pelayanan kesehatan seksual diselenggarakan sesuai standar. Bab IV pasal 26,27,28,29 pelayanan kesehatan seksual.

Berdasarkan pada kebijakan program pemerintah cenderung pada kebermanfaatn masyarakat sasaran namun disisi pendanan ada kebijakan yang kurang mendukung, selain itu disebabkan karena sumber daya tenaga yang kurang memadai untuk bisa menjangkau masyarakat sasaran.hal tersbut dapat dianalisi bahwa diperlukan pemecahan masalah, namun jika masalah anggaran dana tidak tersedia cukup bisa menjadi penyebab sasarn program akan terjadi penurunan, kondisi tersbut dapat dimaknai bahwa implementasi kebijakan perlu dikaji berdasarkan perspektif implementasi, proses dan perspektif hasil, pada perspektif proses dapat dikatakan berhasil jika antara pelaksanaan sesuai denga petunjuk dan ketentuan pelaksaan pembuat kebijakan dan pihak yang terlibat baik sebagai agent, kelompok sasaran serta manfaat program.

Promkes dikatakan berhasil jika membawa pengaruh dan perubahan yang dapat dirasionalisasi dengan keadaan Ingkungan perubahan.

Mengacu pada hasil bahwa pelaksaan promkes dimasyarakat selain mengacu ke program juga disesuaikan dengan kebutuhan masyarakat atau atas permintaan masyarakat, akses ini diartikan bahwa kebijakan program bersifat lebih fleksibel mengingat keterbatasan sumber daya tenaga bidan sehingga pelaksanaan promkes lebih tepat kepada kebutuhan masyarakat, bisa menjadi tidak berpihak ke pada azas manfaat jika program promkes yang dilakukan hanya berdasar pada program kebijakan yang sudah baku karena hal tersebut akan menujukkan bahwa kebijakan tidak bersifat otonom kepada kebutuhan masyarakat bahkan apabila tidak akuntabel akan menjadi kebijakan yang bermuara pada kebijakan sepihak tanpa melibatkan kebutuhan riil dari pengguna yaitu masyarakat sasaran.

\section{PERAN BIDAN DALAM PROMOSI KESEHATAN}

Berdasarkan hasil penelitian didapatkan dari bahwa kendala pelaksanaan karena tenaga bidan terbatas. Menurut Renstra Dinkes Sleman tahun 2017 dipaparkan bahwa data kecukupan jumlah bidan 589 dengan perhitungan rasio/ 100.000, telah terpenuhi, dibandingkan dengan data dinkes tersebut dengan cakupan promosi kesehatan yang didapatkan dari wawancara kepada informan belum terjangkau secara merata sesuai kebijakan program, hal tersebut disebabkan karena belum sebaran jumlah kecukupan bidan belum merata sehingga menjadi kendala ketercapaian program, ketidak tercapaian program bukan karena faktor kinerja yang kuarng baik namun karena masih adanya tumpang tindih job pada masing masing program dimana tenaga bidan harus merangkap jabatan sehingga prioritas masalah menjadi sulit terselaesaikan. Sesuai dengan temuan data Dinas kesehatan kabupaten Sleman yang dilaporkan pada hasil cakupan pelaksanaan program tahun 2016 didapatkan bahwa masih adanya tantangan dan peluang yang diperlukan peran bidan secara terfokus pada tantangan adanya peningkatan kasus penyakit tidak menular, kanker servik merupakan bagian dari kriteria penyakit tidak menular yang perlu penangan melalui upaya promosi kesehatan, Pelaksanaan kebijakan program pelayanan kesehatan dilaksanakan oleh semua bidan, baik bidan diunit rawat jalan maupun rawat inap, Mengacu pada hasil bahwa cakupan promkes yang disampaikan 
oleh Informan 1 dan 3 bahwa "cakupan belum maksimal terjadi salah satunya juga karena kendala sumber daya tenaga bidan yang belum tercukupi jika dibandingkan dengan jumlah fasilitas dan program posbindu sebanyak 60 , sedangkan tenaga bidan yang dialokasikan pada kegiatan promkes di posyandu hanya 4 bidan diwilayah kerja Puskesmas tempel, kondisi tersbut menjadi evaluasi bahwa analisis dari ketidak tercapaian peran bidan adalah karena faktor keterbatasan sumber daya, sedangkan kesadaran masyarakat sendiri masih belum tercapai, terlebih lagi kesadaran untuk deteksi dini kanker, salah satu data yang disampaikan oleh informan 1 yang menyatakan bahwa" masyarakat masih harus dioyak oyak dulu untuk mau melakukan upaya deteksi dini kanker msekipun mereka sudah tahu pentingnya periksa, namun juga masih ada anggapan malu untuk periksa. Hasil ini sesuai dengan jurnal Nurul ( 2016), dipaparkan bahwa masayarakat masih memegang prinsip malu untk periksa jika tidak karena terpaksa, hasil ini jika dinalogkan dengan peraturan pemerintah bukan karena peran bidan murni namun karena kelompok masyarakat sasaran yang belum sepenuhnya sadar arti pentingnya promosi dan dteksi dini kanker rahim seperti disebutkan dalam Kepmenkes RI Nomor 369/MENKES/SK/III/2007 tentang Standar Profesi Bidan, dijelaskan didalam lampiran keputusan bahwa salah satu tugas bidan pada pelaksanaan pelayanan kebidanan memiliki Sasaran pelayanan kebidanan adalah individu, keluarga, dan masyarakat yang meliputi upaya peningkatan, pencegahan, penyembuhan dan pemulihan pelayanan kebidanan. Secara spesifik diatur sesuai kompetensi bidan pada kompetensi memberikan asuhan kebidanan pada ibu/wanita dengan gangguan reproduksi, seorang bidan harus memiliki pengetahuan dasar tentang Penyuluhan kesehatan mengenai kesehatan reproduksi, penyakit menular seksual (PMS), HIVIAIDS, mengacu pada standar kompetensi bidan bahwa pelaksanaan promkes kespro di PKM Tempel tahun 2018-2019 telah berjalan sesuai dengan kewenangan bidan, bahkan pada pelaksanaan konseling hasil juga telah dilakuakn dengan prinsip otonomi klien secara holistic (bio, psikososial) dengan melalui langkah mempersiapkan mental kesiapan pasien menrima hasil pemeriksaan jika memang hasilnya tidak seprti harapan. Peran tersebut telah sesuai dengan peran sebagai Edukator yaitu memberikan pendidikan kesehatan dan konseling dalam asuhan dan pelayanan kebidanan di setiap tatanan pelayanan kesehatan agar mereka mampu memelihara dan meningkatkan kesehatan masyarakat, Fungsi bidan sebagai educator yaitu Melaksanakan pendidikan kesehatan dan konseling dalam asuhan dan pelayanan kebidanan.

Peran lain seperti yang didapatkan dari hasil yang dijelaskan oleh Informan 2 dan 3, bahwa salah satu kegiatan promkes dengan melakukan pelatihan kader yang selanjutnya pada pelaksanaan promkes di posbindu adalah bisa dilaksanakan oleh kader.hal tersebut peran bidan telah terlaksana, jika dianalogkan dengan peran edukator yaitu membina kader dan kelompok masyarakat, mentorship dan preseptorsip bagi calon tenaga kesehatan dan bidan baru. Tidak bisa dipungkiri bahwa makna promosi kesehatan sangat diperlukan adanya peran bidan, promosi kesehatan jika dianalogkan dengan peningkatan pengetahuan maka diperlukan adanya penyuluhan agar paradigma masyarakat bisa berubah, jurnal penelitian G Suvia, (2016) di Yogyakarta memaparkan bahwa ada hubungan antara penyuluhan terhadap sikap pencegahan penyakik kanker servik.

Peran Promosi kesehatan sangat diperlukan pada upaya pencegahan suatu penyakit, dipaparkan bahwa antara pengetahuan sebelum penyuluhan dan sesudah terdapat perbedaan pada pengaruh pada pengambilan keputusan dari 36 responden dengan kriteria baik sebelum adalah $55 \%$, sesudah penyuluhan menjadi 94,5\%.hasil ini menujukkan bahwa salah satu permasalahan rendahnya cakupan deteksi dini kanker servik di wilayah Puskesmas Sleman adalah disebabkan karena faktor masih kurangnya cakupan promosi kesehatan deteksi dini kanker servik. 


\section{KESIMPULAN DAN SARAN}

Kebijakan Dinas Kesehatan Kabupaten Sleman tentang peran bidan pada promosi kesshatan reproduksi Deteksi dini kanker servik di Wilayah Kerja Puskesmas Tempel telah dilaksanakan namun ketercapaian program belum sesuai target sasaran. Peran bidan belum maksimal, hal tersebut dikarenakan adanya keterbatasan sumber daya tenaga bidan yang belum bisa menjangkau wilayah kerja sesuai program kebijakan sehingga kegiatan promkes lebih diutamakan sesuai prioritas masalah dan kondisi masyarakat. Puskesmas perlu mengatur kembali tata cara penerapan dan kebijakan pelaksanaan dan standar pelaksanaan kegiatan yang lebih fleksibel sesuai dengan sumber daya dan cakupan sasaran target program yang belum tercapai agar dikembangkan kembali.

\section{REFERENSI}

Afiyanti, Y., \& Rachmawati, I.N. 2014. Metodologi Penelitian Kualitatif dalam Riset Keperawatan. Raja Grafindo Persada: Jakarta.

AG Subarsa,2006, Analisis Kebijakan Publik, Pustaka pelajar, Yogyakarta,

Dinkes Daerah Istimewa Yogyakarta, 2014.

Dewi, Sawitri \& Adiputra, 2012, Determinan kanker servik di Kota Yogyakarta, Skripsi.

http://www.ijhssnet.com/journals/Vol 3 No 17

September 2013/12.pdf. Diakses tanggal 19 februari 2016.

BKKBN. 2015. Rencana Strategis Badan Kependudukan dan Keluarga Berencana Nasional Tahun 2015-2019. BKKBN: Jakarta

Dinkes Sleman, 2018, Perubahan Rencana Strategis Dinas Kesehatan Sleman 2016-2021

https://dinkes.slemankab.go.id/wpcontent/uploads/2018/09/RENSTRADINKES-SLEMAN.pdf

Ermiati, Restuning Widiasih, 2018, Upaya Promosi dan Prevensi Kesehatan Reproduksi Wanita oleh Petugas Kesehatan. Idea Nursing Journal Vol. IX No. 12018 ISSN : 2087-2879, e-ISSN : $2580-2445$
Faizah. 2010. Waspada Kanker Serviks, Kaukaba, Yogyakarta

http://www.depkes.go.id/resources/download/pr ofil/PROFIL KAB KOTA 2014/3471 DI Y Kota Yogyakarta 2014.hal 34-35. diakses 31 Agustus 2017 jam 11.00.

Fitri Setianingsih. 2017. Hubungan Pengetahuan WUS tentang Deteksi Dini Kanker Servik Dengan Upaya Pencegahan Yang Dilakukan WUS, Skripsi, Universitas 'Aisyiyah Yogyakarta,

G Suvia, (2016), Peran Penyuluhan Terhapadap perubahan perilaku deteksi dini kanker servik, Skripsi, www. unisayogya.ac.id.

Gilang A.P. 2014, Pengaruh Pelatihan Kader Tentang Posyandu Terhadap Kemampuan Pengelolaan Posyandu Di Desa Sendang sari Kulon Progo, Naskah Publikasi, www.unisayogya.co.id.

www/republika, co,ic. Prevalensi kanker di Yogyakarta, 2015

Manuaba 2009, Kesehatan Reproduksi Wanita, EGC. Jakarta. Hal 209-210

Notoatmodjo, S., (2012). Promosi Kesehatan dan IImu Perilaku, PT. Rineka Cipta, Jakarta

Riset Kesehatan Dasar, 2013.

Sinclair C ( 2010),Buku saku Bidan, EGC, Jakarta hal 529-549

Sugiyono,2011, Metodologi Penelitian Kesehatan, Reineka Cipta, Jakarta, hlm 39

Soimah N,2017, Pengetahuan pasangan Usia Subur tentang Deteksi Dini Kanker Rahim dan akses layanan pemeriksaan IVA, Jurnal Penelitian UNISA.

Samadi, 2011, I know evering about kanker serviks mengenali, mencegahnya dan bagaimana menjalani pengobatan, Tiga Serangkai Pustaka Mandiri, Solo.

Undang -Undang Dasar tahun 1945.

Undang-Undang No 36 tahun 2009 Tentang kesehatan

Undang-Undang Nomor 14 tahun 2008 tentang Keterbukaan Informasi Publik

Peraturan Pemerintah No 61 tahun 2014 tentang Kesehatan Reproduksi 